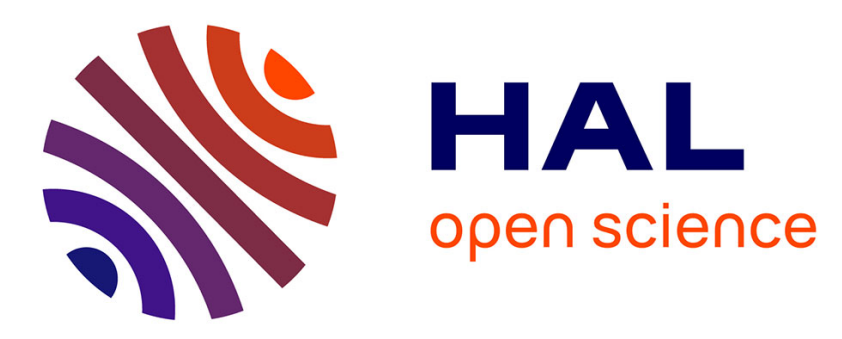

\title{
Terpyridine-tetrathiafulvalene hybrid ligands and their electroactive metal complexes
}

Esmah Belhadj, Abdelkrim El-Ghayoury, Emilie Ripaud, Leokadiya Zorina, Magali Allain, Patrick Batail, Miloud Mazari, Marc Sallé

\section{- To cite this version:}

Esmah Belhadj, Abdelkrim El-Ghayoury, Emilie Ripaud, Leokadiya Zorina, Magali Allain, et al.. Terpyridine-tetrathiafulvalene hybrid ligands and their electroactive metal complexes. New Journal of Chemistry, 2013, 37 (5), pp.1427-1436. 10.1039/c3nj00041a . hal-03344540

\section{HAL Id: hal-03344540 \\ https://univ-angers.hal.science/hal-03344540}

Submitted on 15 Sep 2021

HAL is a multi-disciplinary open access archive for the deposit and dissemination of scientific research documents, whether they are published or not. The documents may come from teaching and research institutions in France or abroad, or from public or private research centers.
L'archive ouverte pluridisciplinaire $\mathbf{H A L}$, est destinée au dépôt et à la diffusion de documents scientifiques de niveau recherche, publiés ou non, émanant des établissements d'enseignement et de recherche français ou étrangers, des laboratoires publics ou privés. 
Cite this: NewJ.Chem., 2013, 37, 1427

Received (in Montpellier, France) 10th January 2013,

Accepted 14th February 2013

DOI: 10.1039/c3nj00041a

www.rsc.org/njc

\section{Terpyridine-tetrathiafulvalene hybrid ligands and their electroactive metal complexes $\uparrow$}

\author{
Esmah Belhadj, ${ }^{\text {ab }}$ Abdelkrim El-Ghayoury, ${ }^{\text {a }}$ Emilie Ripaud, ${ }^{a}$ Leokadiya Zorina, ${ }^{c}$ \\ Magali Allain, ${ }^{a}$ Patrick Batail, ${ }^{* a}$ Miloud Mazari ${ }^{b}$ and Marc Sallé ${ }^{\star a}$
}

\section{Introduction}

As formulated in a Bendikov-Wudl-Perepichka review, the sulfur heterocycle 2,2'-bis(1,3-dithiolylidene) TTF, and its very numerous derivatives, are remarkable due to their low first oxidation potential and the unusual stability and solid state properties of the radical cations which result from the oneelectron oxidation of their parent molecules. ${ }^{1}$ They have been widely used as the $\pi$-donor components in the preparation of molecular conductors and superconductors ${ }^{2}$ and have also found widespread use as redox switches in a myriad of recent molecular and supramolecular architectures. ${ }^{3}$ In particular, on-going research is devoted to covalently link a coordinating or binding unit to a redox-active TTF core, to produce either TTF-based redox-switchable receptors designed for guest sensing applications in solution, or to install interplay between two or more physical properties, such as magnetism and electrical conductivity, in solid state multifunctional constructs. ${ }^{4}$ Monoor polydentate ligands and their corresponding electroactive metal complexes have been reported, ${ }^{5}$ including for example,

\footnotetext{
${ }^{a}$ LUNAM Université, Université d'Angers, CNRS UMR 6200,

Laboratoire MOLTECH-Anjou, 2 bd Lavoisier, 49045 Angers Cedex, France. E-mail: abdelkrim.elghayoury@univ-angers.fr, patrick.batail@univ-angers.fr, marc.salle@univ-angers.fr; Fax: +33 2417354 05; Tel: +33 241735492

${ }^{b}$ Laboratoire de Synthèse Organique Appliquée d'Oran, Université d'Oran Es-Sénia, Algérie

${ }^{c}$ Institute of Solid State Physics RAS, 142432 Chernogolovka MD, Russia $\dagger$ Electronic supplementary information (ESI) available: CV and UV-Vis titrations spectra. CCDC 917571-917574. For ESI and crystallographic data in CIF or other electronic format see DOI: 10.1039/c3nj00041a
}

metal complexes of phosphines, ${ }^{6}$ dithiolates, ${ }^{7}$ acetylacetonates, ${ }^{8}$ pyridines, ${ }^{9}$ and of Schiff bases. ${ }^{10}$ In that context, oligopyridines, including 2,2'-bipyridine, 1,10-phenanthroline and 2,2': $6^{\prime}, 2^{\prime \prime}$ terpyridine are well-documented and appealing chelating ligands due to their strong and topologically predictable binding ability to essentially all metal ions. ${ }^{11}$ While a few TTF-based ligands have been prepared with $2,2^{\prime}$-bipyridine ${ }^{12}$ and 1,10phenanthroline, ${ }^{13}$ surprisingly, only one example of a $2,2^{\prime}: 6^{\prime}, 2^{\prime \prime}$ terpyridine-TTF hybrid has been reported so far, yet with no further investigation of their metal complexes. ${ }^{14}$

We now report the synthesis, crystal structures and electronic properties of two terpyridine-appended TTFs chelating ligands that integrate distinctive linkers between both active subunits. Their ability to form stable, electroactive metal complexes was evaluated and the electronic conjugation through both linkers is compared using cyclic voltammetry and electronic absorption analyses. In addition, the crystal structure of the two solvates of ligand $\mathbf{1}$, as well as of the metal complexes of ligand 2 , the neutral (zinc complex) or the positively charged (nickel complex) are described.

\section{Experimental}

\section{Syntheses}

(4'-Amido-2,2':6' $\mathbf{2}^{\prime \prime}$-'terpyridyl)-6,7-ethylenedithiotetrathiafulvalene (1). In a three-necked flask, under a nitrogen atmosphere, $4^{\prime}$-amino-2,2': $6^{\prime}, 2^{\prime \prime}$-terpyridine $(0.15 \mathrm{~g}, 0.60 \mathrm{mmol})$ was dissolved in $10 \mathrm{~mL}$ of freshly distilled tetrahydrofuran, and $1 \mathrm{~mL}$ of triethylamine was added. A solution of ethylenedithiotetrathiafulvalene acid chloride $(0.22 \mathrm{~g}, 0.60 \mathrm{mmol})$ in $15 \mathrm{~mL}$ of 
tetrahydrofuran was added dropwise. The mixture was stirred overnight and the solvent was removed by distillation under vacuum. The resulting mixture was then extracted from water using dichloromethane $(3 \times 75 \mathrm{~mL})$. The organic phases were collected, dried over sodium sulfate and evaporated under vacuum to afford an orange red solid. Recrystallisation from a methanol dimethylsulfoxide mixture yielded orange-red single crystals that were suitable for X-ray analysis. Yield $0.100 \mathrm{~g}$ (29\%); $\lambda_{\max }\left(\mathrm{CH}_{2} \mathrm{Cl}_{2}-\mathrm{CH}_{3} \mathrm{CN}, 1 / 1, \mathrm{v} / \mathrm{v}\right) / \mathrm{nm} 281$ ( $\left.\varepsilon / \mathrm{dm}^{3} \mathrm{~mol}^{-1} \mathrm{~cm}^{-1} 33200\right), 309$ (24 400), 447 (3160). ${ }^{1} \mathrm{H}$ NMR $\left(500.13 \mathrm{MHz}, \mathrm{CDCl}_{3}, 25{ }^{\circ} \mathrm{C}\right): \delta=8.63 \mathrm{ppm}(\mathrm{d}, J=6.86 \mathrm{~Hz}, 2 \mathrm{H})$, $8.53(\mathrm{~d}, J=6.86 \mathrm{~Hz}, 2 \mathrm{H}), 7.93(\mathrm{~m}, 2 \mathrm{H}), 7.66(\mathrm{~m}, 2 \mathrm{H}), 7.42$ $(\mathrm{m}, 2 \mathrm{H}), 6.34(\mathrm{~m}, 2 \mathrm{H}), 3.37(\mathrm{~s}, 4 \mathrm{H}) .{ }^{13} \mathrm{C}-\left\{{ }^{1} \mathrm{H}\right\}$ NMR $(125 \mathrm{MHz}$, $\left.\left[\mathrm{D}_{6}\right] \mathrm{DMSO}, 25^{\circ} \mathrm{C}\right): \delta=162.6(\mathrm{C}=\mathrm{O}), 156.6,155.1,149.5,149.2$, 137.3, 124.8, 124.1, 120.8 (C=C-Terpy), 113.4, 111.7, 105.8, $104.0(\mathrm{C}=\mathrm{C}), 29.7\left(\mathrm{CH}_{2}-\mathrm{CH}_{2}\right)$. Elemental analysis (\%) calcd for $\mathrm{C}_{24} \mathrm{H}_{16} \mathrm{~N}_{4} \mathrm{OS}_{6}$ : C 50.68, H 2.84, N 9.85; found: C 50.53, H 2.71, $\mathrm{N}$ 9.74. MALDI-TOF MS calcd: $m / z=567.9 \mathrm{Da}$, found: $m / z 567.9[\mathrm{M}]^{+}$.

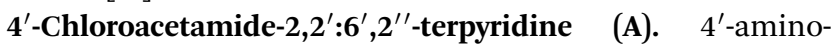
$2,2^{\prime}: 6^{\prime}, 2^{\prime \prime}$-terpyridine $(0.100 \mathrm{~g} ; 0.4 \mathrm{mmol})$ was dissolved in freshly distilled THF $10 \mathrm{~mL}$ and triethylamine $(1 \mathrm{~mL})$ was added. The resulting solution was cooled to $0{ }^{\circ} \mathrm{C}$, in an ice bath, and a solution of chloroacetyl chloride $(0.1 \mathrm{~mL}$ in anhydrous THF $5 \mathrm{~mL}$ ) was added dropwise. After $1 \mathrm{~h}$, the solvent was evaporated and the white solid was washed with water and then dried under vacuum. The product was used without further purification in the next step.

2-(4'-Thioacetamide-2,2' $: 6^{\prime}, 2^{\prime \prime}$-terpyridyl)-3,6,7tris(methylsulfanyl)-6,tetrathiafulvalene (2). A solution of cesium hydroxide monohydrate $(0.033 \mathrm{~g} ; 0.200 \mathrm{mmol})$ in methanol $(1 \mathrm{~mL})$ was added to a solution of 2-(2-cyanoethylsulfanyl)-3,6,7-tris(methylsulfanyl)-6,7-tetrathiafulvalene (0.086 g; $0.200 \mathrm{mmol}$ ) in DMF (5 mL). The resulting dark solution was stirred for 30 minutes and the $4^{\prime}$-chloroacetamide- $2,2^{\prime}: 6^{\prime}, 2^{\prime \prime}$ terpyridine (A) $(0.065 \mathrm{~g} ; 0.200 \mathrm{mmol})$ was added. The reaction mixture was stirred, under argon, for $24 \mathrm{~h}$. Dichloromethane was added and the mixture was washed three times with brine and with water. After extraction, the organic layers were collected, dried over $\mathrm{MgSO}_{4}$ and the solvent was evaporated under vacuum. The obtained residue was then passed over silica gel column that was treated by triethylamine, using a gradient of eluent (dichloromethane then dichloromethanemethanol, 9.9/0.1, v/v). After solvent evaporation an orange powder of ligand 2 was obtained (0.053 g, 40\%). M.p. $=190{ }^{\circ} \mathrm{C}$. $\lambda_{\max }\left(\mathrm{CH}_{2} \mathrm{Cl}_{2}-\mathrm{CH}_{3} \mathrm{CN}, 1 / 1, \mathrm{v} / \mathrm{v}\right) / \mathrm{nm} 277\left(\varepsilon / \mathrm{dm}^{3} \mathrm{~mol}^{-1} \mathrm{~cm}^{-1}\right.$ 48 800), 331 (18 400), 386 (4880). ${ }^{1} \mathrm{H}$ NMR (300 MHz, $\mathrm{CDCl}_{3}$, $\left.25{ }^{\circ} \mathrm{C}\right): \delta=9.31(\mathrm{~s}, 1 \mathrm{H}, \mathrm{NH}) ; 8.73(\mathrm{~s}, 1 \mathrm{H}, \mathrm{CH}=\mathrm{C}$, Terpy); 8.71-8.73 (m, 2H, $\mathrm{CH}=\mathrm{N}$, Terpy); 8.60-8.64 (m, 2H, CH, Terpy); 7.85-7.91 (m, 2H, CH, Terpy); 7.34-7.38 (m, 2H, CH, Terpy); 3.77 (s, 2H, $\left.\mathrm{CH}_{2} \mathrm{~S}\right), 2.49(\mathrm{~s}, 1 \mathrm{H}, \mathrm{SMe}) ; 2.44(\mathrm{~s}, 1 \mathrm{H}$, $\mathrm{SMe}) ; 2.41$ (s, 1H, SMe). ${ }^{13} \mathrm{C}-\left\{{ }^{1} \mathrm{H}\right\}$ NMR (75 MHz, $\mathrm{CDCl}_{3}$, $\left.25^{\circ} \mathrm{C}\right): \delta=165.52(\mathrm{C}=\mathrm{O}), 156.96(\mathrm{C}=\mathrm{C}) ; 155.81,149.22$, 146.42, 136.79, 135.53, 128.07, 127.18, 123.96, 121.20, 119.92, 114.97, 114.9, $110.79(\mathrm{C}=\mathrm{C}), 108.86,104.5,40.50\left(\mathrm{CH}_{2} \mathrm{~S}\right)$, $19.72\left(\mathrm{CH}_{3} \mathrm{~S}\right), 19.33\left(\mathrm{CH}_{3} \mathrm{~S}\right)$. Elemental analysis (\%) calcd for
$\mathrm{C}_{26} \mathrm{H}_{22} \mathrm{~N}_{4} \mathrm{OS}_{8}$ : C 47.10, H 3.34, N 8.45; found: C 46.91, H 3.29, $\mathrm{N}$ 8.31. MALDI-TOF MS calcd: $m / z=661.9$ Da. found: $m / z 662[\mathrm{M}]^{+}$.

$(\mathbf{M e S})_{3}$-TTF-SCH ${ }_{2}$ CONH-Tpy-ZnCl $\mathbf{Z n}_{2} \cdot \mathbf{M e O H}$ (3). In a test tube, a solution of $2(5 \mathrm{mg}, 0.007 \mathrm{mmol})$ in $\mathrm{CH}_{2} \mathrm{Cl}_{2}(2 \mathrm{~mL})$ was mixed with a solution of $\mathrm{ZnCl}_{2}(1.03 \mathrm{mg}, 0.007 \mathrm{mmol})$ in methanol (1 $\mathrm{mL}$ ) and ultrasonicated for $2 \mathrm{~min}$. On top of the resulting solution diethylether was added, which lead to the formation of single crystals of 3 after one week. Yield: $4 \mathrm{mg}$ (71\%). ESI-MS: $m / z$ (M-Cl: $762.61 \mathrm{Da})$.

$\left[\left\{(\mathrm{MeS})_{3} \text {-TTF-SCH} \mathrm{THONH}_{2} \mathrm{COpy}\right\}_{2} \mathrm{Ni}\right] \cdot\left(\mathrm{ClO}_{4}\right)_{2} \cdot \mathbf{0 . 5}\left(\mathrm{H}_{2} \mathrm{O}\right)(4)$. In a test tube, a solution of $2(5 \mathrm{mg}, 0.007 \mathrm{mmol})$ in $\mathrm{CH}_{2} \mathrm{Cl}_{2}(2 \mathrm{~mL})$ was mixed with a solution of $\mathrm{Ni}\left(\mathrm{ClO}_{4}\right)_{2} \cdot 6 \mathrm{H}_{2} \mathrm{O}(1.19 \mathrm{mg}$, $0.097 \mathrm{mmol})$ in $\mathrm{CH}_{3} \mathrm{CN}(1 \mathrm{~mL})$ and ultrasonicated for $2 \mathrm{~min}$. Single crystals of $\mathbf{4}$ were grown by liquid-liquid slow diffusion of the resulting solution into a layer of diethyl ether. Yield: $4.5 \mathrm{mg}$ (81\%). ESI-MS: $m / z\left(\left[\mathrm{M}-\mathrm{ClO}_{4}\right]^{+}=1482.46 \mathrm{Da}\right)$ and $\left(\left[\mathrm{M}-2 \mathrm{ClO}_{4}\right]^{2+}=691.72 \mathrm{Da}\right)$.

\section{X-ray crystallography}

The experimental X-ray diffraction data for single crystals of 1.DMSO, 1. $\mathbf{M e O H}$, complex 3 and complex 4 were collected at different temperatures (see Table 1) using a Bruker Nonius Kappa CCD diffractometer with MoK $\alpha$-radiation $(\lambda=0.71073 \AA$, graphite monochromator). The combined $\varphi$ - and $\omega$-scan method was used for data collection. An empirical absorption correction of experimental intensities was applied for all data using the SADABS program. ${ }^{15}$

The structures were solved by a direct method followed by Fourier syntheses and refined by a full-matrix least-squares method using the SHELX-97 programs. ${ }^{16}$ All non-hydrogen atoms were refined in an anisotropic approximation. H-atoms were placed in idealized positions and refined using a riding model. The PLATON/SQUEEZE procedure was applied for the determination of the structure of $\mathbf{3}$, to take into account the scattering contribution from strongly disordered $\mathrm{MeOH}$ solvent molecules. Crystals of complex 4 were characterized by twinning, and an X-ray diffraction experiment was performed after manual separation of the two twin domains by cutting of the crystal. Details of the experimental data collection and structure refinement are summarized in Table 1. CCDC 917572 (1·MeOH), 917571 (1·DMSO), 917574 (complex 3) and 917573 (complex 4). $†$

\section{Cyclic voltammetry}

Cyclic voltammetry (CV) experiments were performed in a three-electrode cell equipped with a platinum milli-electrode, a platinum wire counter-electrode and a silver wire used as a quasi-reference electrode. The electrochemical experiments were carried out under a dry and oxygen-free atmosphere $\left(\mathrm{H}_{2} \mathrm{O}<1 \mathrm{ppm}, \mathrm{O}_{2}<1 \mathrm{ppm}\right) \mathrm{CH}_{2} \mathrm{Cl}_{2}-\mathrm{CH}_{3} \mathrm{CN}\left(\right.$ ca. $\left.1-210^{-5} \mathrm{M}\right)$ with $\mathrm{Bu}_{4} \mathrm{NPF}_{6}$ (TBAP) $(0.1 \mathrm{M})$ as the supporting electrolyte. Voltammograms were recorded on an EGG PAR 273A potentiostat with positive feedback compensation. Based on repetitive measurements, the absolute errors of the potentials were estimated to be around $\pm 5 \mathrm{mV}$. All the cyclic voltamograms were calibrated versus the oxidation potential of ferrocene. 
Table 1 Main crystal data and details of experimental data collection and structure refinement

\begin{tabular}{|c|c|c|c|c|}
\hline & 1.MeOH & 1.DMSO & Complex 3 & Complex 4 \\
\hline Temperature/K & $200(2)$ & $293(2)$ & $180(2)$ & $180(2)$ \\
\hline Chemical formula & $\mathrm{C}_{25} \mathrm{H}_{20} \mathrm{~N}_{4} \mathrm{O}_{2} \mathrm{~S}_{6}$ & $\mathrm{C}_{26} \mathrm{H}_{22} \mathrm{~N}_{4} \mathrm{O}_{2} \mathrm{~S}_{7}$ & $\mathrm{C}_{27} \mathrm{H}_{26} \mathrm{Cl}_{2} \mathrm{~N}_{4} \mathrm{O}_{2} \mathrm{~S}_{8} \mathrm{Zn}$ & $\mathrm{C}_{52} \mathrm{H}_{45} \mathrm{Cl}_{2} \mathrm{~N}_{8} \mathrm{NiO}_{10.5} \mathrm{~S}_{16}$ \\
\hline Molecular weight & 600.8 & 646.9 & 831.3 & 1592.5 \\
\hline Crystal system & Monoclinic & Monoclinic & Triclinic & Triclinic \\
\hline$a / \AA$ & $25.001(2)$ & $20.167(3)$ & $8.1990(8)$ & $8.967(1)$ \\
\hline$b / \AA$ & $11.856(1)$ & $19.979(5)$ & $11.455(1)$ & $17.786(4)$ \\
\hline$c / \AA$ & $20.044(1)$ & $15.367(4)$ & $19.958(2)$ & $21.378(1)$ \\
\hline$\alpha /^{\circ}$ & 90 & 90 & $96.439(7)$ & $83.02(1)$ \\
\hline$\beta /^{\circ}$ & $117.164(7)$ & $113.93(1)$ & $90.342(7)$ & $88.313(6)$ \\
\hline$\gamma /{ }^{\circ}$ & 90 & 90 & $110.707(8)$ & $77.74(2)$ \\
\hline$V / \AA^{3}$ & $5286.0(7)$ & $5659(2)$ & $1740.2(3)$ & $3307.0(8)$ \\
\hline Space group, $Z$ & $C 2 / c, 8$ & $C 2 / c, 8$ & $P \overline{1}, 2$ & $P \overline{1}, 2$ \\
\hline$\rho_{\text {calc. }} / \mathrm{g} \mathrm{cm}^{-3}$ & 1.510 & 1.519 & 1.586 & 1.599 \\
\hline$\mu / \mathrm{cm}^{-1}$ & 5.50 & 5.91 & 13.73 & 9.41 \\
\hline$T_{\min }, T_{\max }$ & $0.686,0.746$ & $0.694,0.745$ & $0.682,0.803$ & $0.700,0.972$ \\
\hline $2 \theta_{\max } /^{\circ}$ & 55.1 & 50.0 & 58.0 & 54.1 \\
\hline \multirow[t]{3}{*}{ Range of data } & $-31 \leq h \leq 32$ & $-23 \leq h \leq 22$ & $-11 \leq h \leq 11$ & $-11 \leq h \leq 11$ \\
\hline & $-15 \leq k \leq 15$ & $-23 \leq k \leq 22$ & $-15 \leq k \leq 15$ & $-22 \leq k \leq 22$ \\
\hline & $-25 \leq l \leq 26$ & $-18 \leq l \leq 18$ & $-27 \leq l \leq 27$ & $-27 \leq l \leq 27$ \\
\hline Refls collected & 49500 & 26564 & 53602 & 49431 \\
\hline Independent refls & 6039 & 4935 & 9212 & 14074 \\
\hline Refls with $I>2 \sigma(I)$ & 3510 & 2638 & 6830 & 4340 \\
\hline$R_{\text {int }}, R_{\sigma}$ & $0.100,0.086$ & $0.077,0.072$ & $0.074,0.055$ & $0.235,0.355$ \\
\hline No. variables & 336 & 373 & 382 & 817 \\
\hline GoF on $F^{2}$ & 1.070 & 1.074 & 1.050 & 1.028 \\
\hline$R_{1}[I>2 \sigma(I)]$ & 0.0589 & 0.0675 & 0.0590 & 0.1152 \\
\hline$w R_{2}[I>2 \sigma(I)]$ & 0.0841 & 0.1266 & 0.1440 & 0.2286 \\
\hline
\end{tabular}

\section{Results and discussion}

The synthesis of the previously reported 2-amidoterpyridine6,7-ethylenedithio-tetrathiafulvalene ligand [EDT-TTF-CONHTpy (1) $]^{17}$ is presented in Scheme 1. Ethylenedithiotetrathiafulvalene acid chloride was synthesized as previously described ${ }^{18}$ and was reacted with $4^{\prime}$-amino- $2,2^{\prime}: 6^{\prime}, 2^{\prime \prime}$-terpyridine ${ }^{19}$ in the presence of triethylamine to afford EDT-TTF-CONH-Tpy (1) in $67 \%$ yield.

Single crystals of the two solvates of ligand 1, suitable for X-ray analysis were obtained. The 1-DMSO solvate was grown by solvent diffusion of methanol into a concentrated dimethylsulfoxide solution of $\mathbf{1}$, while the $\mathbf{1} \cdot \mathbf{M e O H}$ solvate was obtained by diffusion of diethylether into a methanol solution of 1 .

The non-conjugated analogue, 2-( $4^{\prime}$-thioacetamide- $2,2^{\prime}: 6^{\prime}, 2^{\prime \prime}$ terpyridine)-3,6,7-tris(methylsulfanyl)-tetrathiafulvalene $\left[(\mathrm{MeS})_{3^{-}}\right.$ TTF-SCH $\mathrm{CHNH}_{2} \mathrm{CONy}$ (2) was prepared according to a synthetic procedure depicted in Scheme 2. Reaction of chloroacetylchloride with $4^{\prime}$-amino-2,2' $: 6^{\prime}, 2^{\prime \prime}$-terpyridine in the presence of triethylamine afforded the intermediate $4^{\prime}$-chloroacetamide- $2,2^{\prime}: 6^{\prime}, 2^{\prime \prime}$-terpyridine A. This intermediate A was then reacted with 2-(2-cyanoethylsulfanyl)-3,6,7-tris(methylsulfanyl)-6,7-tetrathiafulvalene ${ }^{20}$ in presence of an equivalent amount of cesium hydroxide, to yield $(\mathrm{MeS})_{3}$-TTF-SCH ${ }_{2}$ CONH-Tpy (2) in $40 \%$ yield.

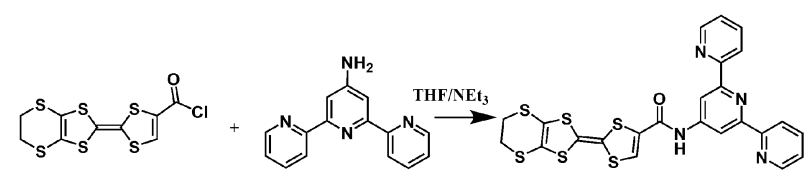

Scheme 1 Synthesis of EDT-TTF-CONH-Tpy (1).

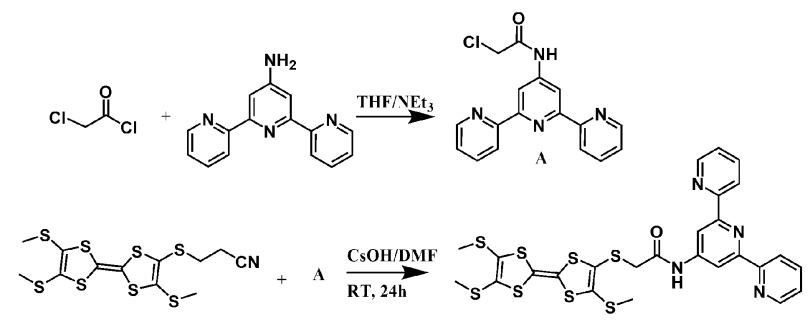

Scheme 2 Synthesis of (MeS) $)_{3}-\mathrm{TTF}-\mathrm{SCH}_{2} \mathrm{CONH}-\mathrm{Tpy}(2)$.

\section{Description of the crystal structures}

EDT-TTF-CONH-Tpy-MeOH (1·MeOH). The solvate 1·MeOH crystallizes in the monoclinic system, space group $C 2 / c$. The asymmetric unit contains one neutral EDT-TTF-CONH-Tpy (1) molecule and one methanol, both in general positions. The ethylene-dithio outer fragment is fully ordered at $200 \mathrm{~K}$. The inner $\pi$-conjugated TTF fragment of molecule $\mathbf{1}$ is not planar (Fig. 1). Instead, significant bending is observed [Fig. 1(b)], which is typical for TTF-based molecules in a neutral state. The dihedral angles between the central $\mathrm{C}_{2} \mathrm{~S}_{4}$ fragment and outer parts of EDT-TTF, denoted as $\beta_{1}$ and $\beta_{2}$ in Fig. 1(a), are listed in Table 2; angle $\beta_{1}$ from the EDT side is as large as 20.51(2) . Angles $\beta_{3}$ and $\beta_{4}$, between the mean planes of each of the constitutive units (EDT-TTF, amide linker, terpyridine) are quite small $\left(4.2^{\circ}\right.$ and $\left.7.3^{\circ}\right)$, a feature suitable to effectively promote electronic communication between the donating and accepting units. Within the terpyridine unit, the pyridine cycles (denoted $\mathrm{i}$ and ii) are in the same plane (Fig. $1 \mathrm{a}$ and $\beta_{5}$ value in Table 2), while the pyridine cycle (denoted iii) is rotating off the co-planar i and ii cycles $\left(\beta_{6}=9^{\circ}\right)$. 


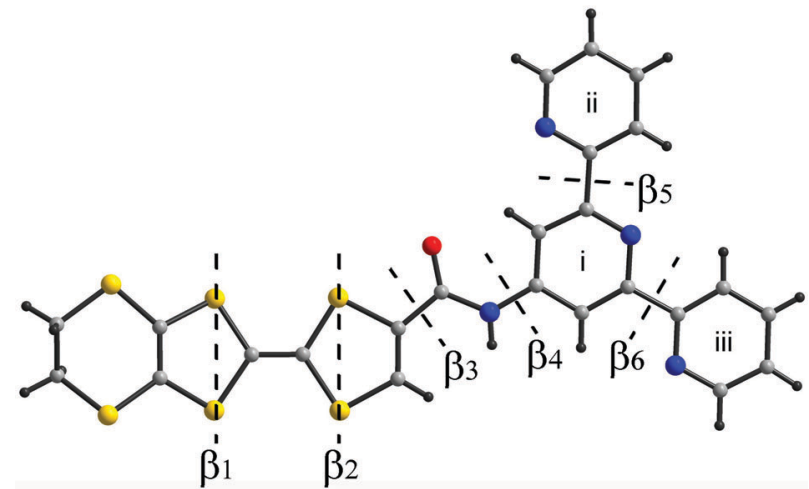

(a)

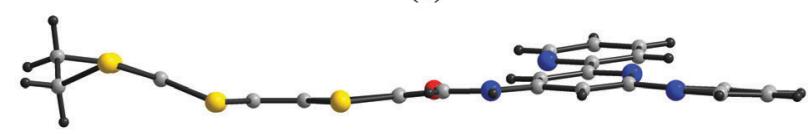

(b)

Fig. 1 (a) Top and (b) side view of molecule $\mathbf{1}$ in $\mathbf{1} \cdot \mathbf{M e O H}$. Values of the dihedral angles $\beta_{1}-\beta_{6}$ are presented in Table 2 .

Table 2 Dihedral angles $\beta_{1}-\beta_{6}$ in ligands 1 and $\mathbf{2}^{a}$

\begin{tabular}{lcllrrr}
\hline Compound & $\beta_{1} /{ }^{\circ}$ & $\beta_{2} /^{\circ}$ & \multicolumn{1}{c}{$\beta_{3} /{ }^{\circ}$} & \multicolumn{1}{c}{$\beta_{4} /^{\circ}$} & \multicolumn{1}{c}{$\beta_{5} /{ }^{\circ}$} & \multicolumn{1}{c}{$\beta_{6} /^{\circ}$} \\
\hline 1.MeOH & $20.51(2)$ & $5.16(7)$ & $4.2(2)$ & $7.3(2)$ & $0.8(1)$ & $9.0(1)$ \\
1.DMSO & $1.79(5)$ & $0.88(7)$ & $11.7(3)$ & $26.9(3)$ & $14.1(2)$ & $4.7(2)$ \\
Complex 3 & $3.87(3)$ & $2.12(3)$ & $43.2(3)$ & $4.5(3)$ & $7.0(1)$ & $13.9(1)$ \\
Complex 4 (ligand 1) & $2.7(1)$ & $2.5(1)$ & $69.6(4)$ & $20.1(4)$ & $11.3(3)$ & $16.0(3)$ \\
Complex 4 (ligand 2) & $9.5(1)$ & $4.9(1)$ & $74.5(3)$ & $23.8(4)$ & $6.1(4)$ & $11.2(4)$ \\
${ }^{a} \beta_{1}-\beta_{6}$ angles are assigned in Fig. 1(a). & & & \\
\hline
\end{tabular}

EDT-TTF-CONH-Tpy (1) molecules self-assemble within the crystal in a herringbone-like manner (Fig. 2). Dimerized molecular

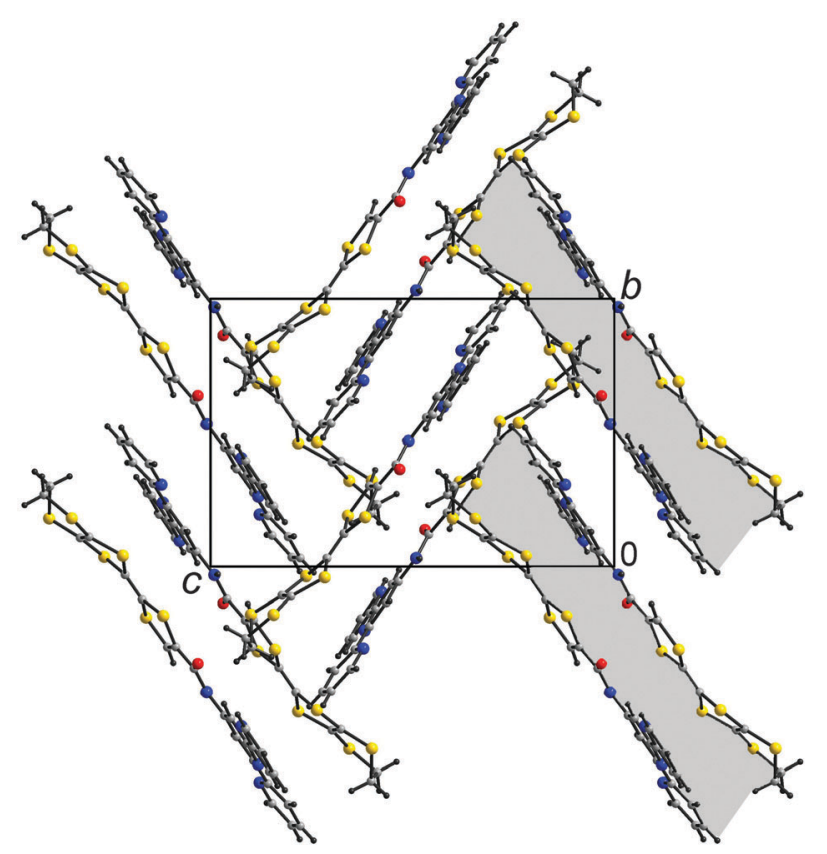

Fig. 2 Molecular packing of a herringbone type in 1.MeOH. Face-to-face dimers in one stack are shown by grey shading. stacks run along the $b$-axis. Face-to-face dimers are marked in Fig. 2 by grey shading. All molecules in the stack are related by inversion symmetry which provides a head-to-tail type of packing. The dimer is stabilized by shortened C..C contacts in the 3.355-3.505(5) Å range. Adjacent dimers interact through overlapping terpyridine fragments, as well as via hydrogen bonding through bridging $\mathrm{MeOH}$ molecules. $\mathrm{H} \cdots \mathrm{O}$ and $\mathrm{H} \cdots \mathrm{N}$ distances along the $\mathrm{N}-\mathrm{H}_{\text {(amide) }} \cdots \mathrm{O}-\mathrm{H}_{\text {(methanol) }} \cdots \mathrm{N}_{\text {(terpy) }}$ chains of the interdimer hydrogen bonds are 2.23 and $2.24 \AA$ A. Note that the oxygen atom from the carbonyl $\mathrm{C}=\mathrm{O}$ group participates only in a weak hydrogen interaction, with the $\mathrm{H}$-atom of the nearest terpyridine, the $\mathrm{H} \cdots \mathrm{O}$ distance in the $\mathrm{C}-\mathrm{H} \cdots \mathrm{O}=\mathrm{C}$ bond is $2.72 \AA^{21}$

Similar herringbone patterns are found in many neutral TTF derivatives including different amide-functionalized EDT-TTF molecules. $^{22}$ The main difference lies in the close proximity of the adjacent slipped stacks in $\mathbf{1} \cdot \mathbf{M e O H}$, leading to the short S. . S van der Waals interstack contact of 3.400(1) A.

EDT-TTF-CONH-Tpy-DMSO (1.DMSO). The pattern of selfassembly and molecular geometry of the solvate 1.DMSO differs significantly from that of 1-MeOH. 1.DMSO crystals have the same $C 2 / c$ symmetry as $\mathbf{1} \cdot \mathbf{M e O H}$. The unit cell contains one crystallographically independent EDT-TTF-CONH-Tpy (1) molecule and one independent solvent in general positions. The molecules of 1 lie stretched along the $b$-axis and are packed into the stacks along the $c$-direction (Fig. 3). Remarkably, the whole crystal is made of parallel molecules so that the usual herringbone pattern of neutral TTF-derivatives is not observed. The EDT-TTF-fragments lie over each other forming a $\delta$-type stack, with alternating parallel head-to-tail and twisted head-tohead overlap modes. Terpyridine fragments form segregated stacks that alternate with EDT-TTF-stacks in a chessboard-like fashion.

Interplane separations in the EDT-TTF-stacks are of $3.7 \AA$ for both parallel and twisted overlaps and there is no intrastack contact between adjacent EDT-TTF parts that is less than the sum of van der Waals radii. The EDT-TTF fragments are rather flattened out in 1.DMSO when compared with their conformation in 1.MeOH crystals (see Fig. 4, Table 2 for comparison of the $\beta_{1}, \beta_{2}$ dihedral angles in both structures). Conversely, the terpyridine part in 1.DMSO, is rotated relative to the TTF-core by a dihedral angle $\left(\beta_{4}\right)$ as large as $26.9(3)^{\circ}$. This results in the

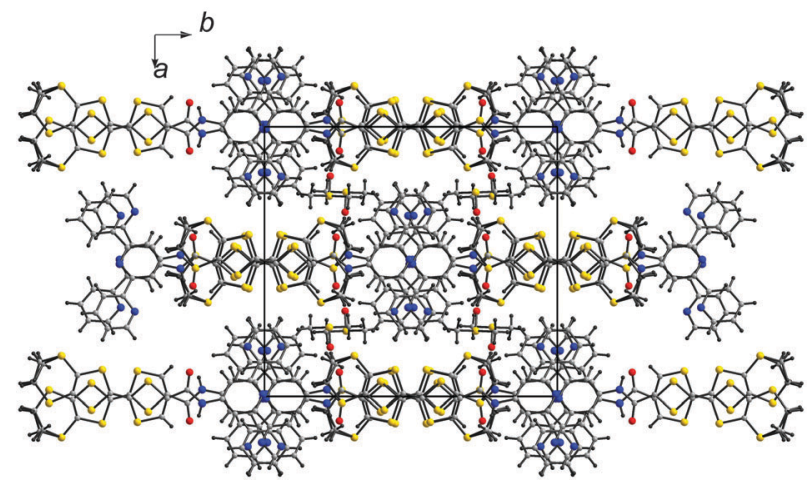

Fig. 3 Crystal structure of 1.DMSO projected along the c-direction. 


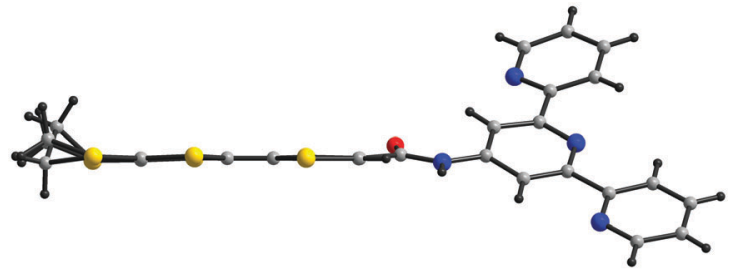

Fig. 4 Side view of the molecule 1 in 1.DMSO (the outer ethylene group of EDT-TTF is disordered over two positions with $0.55 / 0.45$ site occupations at room temperature).

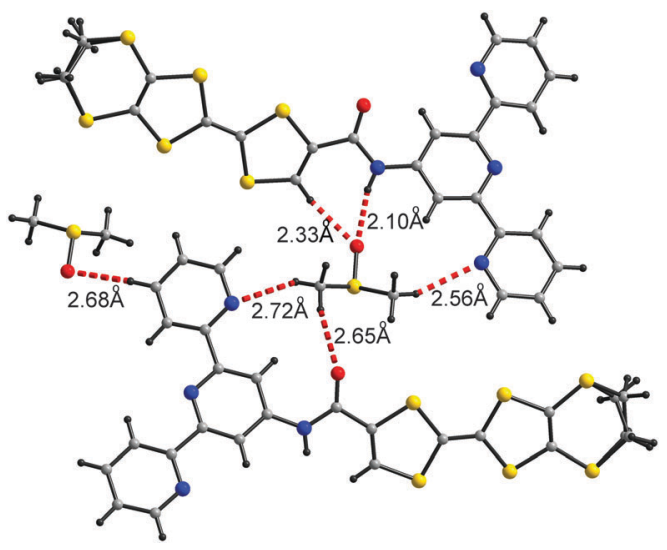

Fig. 5 Hydrogen contacts in 1.DMSO

terpyridine stacks being much closer to each other as exempli-

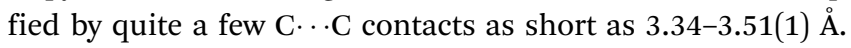

Hydrogen contacts are formed mainly between coplanar molecules from adjacent stacks (Fig. 5), again with participation of the solvent (DMSO in this case) molecules. The shortest is the $\mathrm{N}-\mathrm{H} \cdots \mathrm{O}_{\text {DMsO }}$ hydrogen bond $(\mathrm{H} \cdots \mathrm{O}$ distance is $2.10 \AA$ ), and it is supported by the $\mathrm{C}-\mathrm{H}_{\text {(ЕDT-TTF) }} \cdots \mathrm{O}$ hydrogen contact from the $\mathrm{H}$-atom in the ortho position to the amide group. DMSO methyl groups form hydrogen contacts with the carbonyl oxygen of $\mathbf{1}$ and $\mathrm{N}$ atoms of two of the pyridine cycles. Besides, there is $\mathrm{C}-\mathrm{H}_{\mathrm{pyr}} \cdots \mathrm{O}_{\text {DMSO }}$ contact. Inside the stack there is only one $\mathrm{C}-\mathrm{H} \cdots \mathrm{N}$ contact between the $\mathrm{CH}_{2}$-group of EDT-TTF and the $\mathrm{N}$ atom of the amide group, whose $\mathrm{H} \cdots \mathrm{N}$ distance is $2.67 \AA$.

\section{Electronic absorption spectroscopy}

The electronic absorption spectra of [EDT-TTF-CONH-Tpy (1) and (MeS) ${ }_{3}$-TTF-SCH ${ }_{2} \mathrm{CONH}$-Tpy (2)] were recorded in dichloromethane-acetonitrile solutions (Fig. 6). Both chelating ligands exhibit two strong electronic absorption bands: at $\lambda=281 \mathrm{~nm}$ and $309 \mathrm{~nm}$ for ligand $\mathbf{1}$, with one band observed at $\lambda=277$ for ligand 2, which is accompanied by an hyperfine structure centered at $331 \mathrm{~nm}$. These bands are assigned to the $\pi \rightarrow \pi^{*}$ absorption bands of both the TTF ring and the aromatic terpyridine rings. The broad band observed in the visible region at $\lambda_{\max }=447 \mathrm{~nm}$ for 1 and at $\lambda_{\max }=386 \mathrm{~nm}$ for 2 is characteristic of the intramolecular charge transfer transition (ICT) from the highest occupied molecular orbital in the TTF to the lowest unoccupied molecular orbital in the electron-accepting

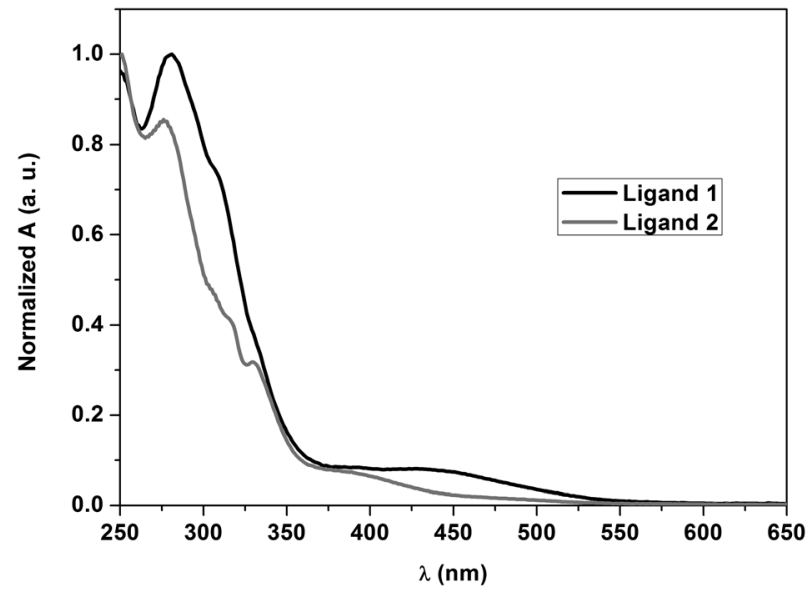

Fig. 6 Electronic absorption spectra of ligands 1 and $2\left(C=2 \times 10^{-5} \mathrm{M}\right.$ in (dichloromethane-acetonitrile, 1/1 (v/v)), room temperature.

terpyridyl unit. ${ }^{23}$ The significantly different values of the ligands is directly correlated to the nature of the linker which associates the donating part (TTF) to the accepting terpyridine unit. Both the donating and accepting units are conjugated to the $-\mathrm{CO}-\mathrm{NH}-$ linker in $\mathbf{1}$, whereas, ligand 2 integrates an additional saturated $\mathrm{SCH}_{2}$ within the linker structure, which results in a decrease of the electronic communication between both fragments. Therefore, such a structural feature leads to a higher value for the ICT band in $\mathbf{1}$ compared to 2 .

\section{Electrochemistry}

The electrochemical behavior of ligands 1 and 2 was investigated by cyclic voltammetry (Table 3). Ligand $\mathbf{1}$ exhibits two reversible oxidations, at $+0.127 \mathrm{~V}$ and $+0.499 \mathrm{~V}$ (Fig. S1, ESI + ), that are significantly anodically shifted when compared to the ones of free EDT-TTF $\left(0.015 \mathrm{~V}\right.$ and $0.200 \mathrm{~V} v s$. $\left.\mathrm{Fc}^{+} / \mathrm{Fc}\right)$. These results confirm the electron-withdrawing effect of the amido group directly linked to the TTF moieties, ${ }^{22}$ as well as the withdrawing effect of the electron deficient terpyridine unit. In the case of ligand 2, two reversible oxidation bands are observed at $+0.035 \mathrm{~V}$ and $+0.346 \mathrm{~V}$. This illustrates a higher $\pi$-donating ability of this ligand compared to 1 , because the presence of the methylene group within the linker structure weakens the electronic conjugation between the TTF and the electron deficient terpyridine parts.

\section{Metal complexation studies: UV/Vis titrations}

The $2,2^{\prime}: 6^{\prime}, 2^{\prime \prime}$-terpyridine unit is a well-established tridentate ligand that forms stable complexes with most transition metal ions. ${ }^{11}$ In particular, because of their $\pi$-acceptor character,

Table 3 Oxidation potentials of ligands 1, 2 and of EDT-TTF for comparison $\left(V\right.$ vs. $\left.\mathrm{Fc}^{+} / \mathrm{Fc}\right)$

\begin{tabular}{lll}
\hline Compound & $E_{1 / 2}{ }^{1}$ & $E_{1 / 2}{ }^{2}$ \\
\hline $\mathbf{1}$ & 0.127 & 0.499 \\
$\mathbf{2}$ & 0.035 & 0.346 \\
EDT-TTF & 0.015 & 0.200
\end{tabular}




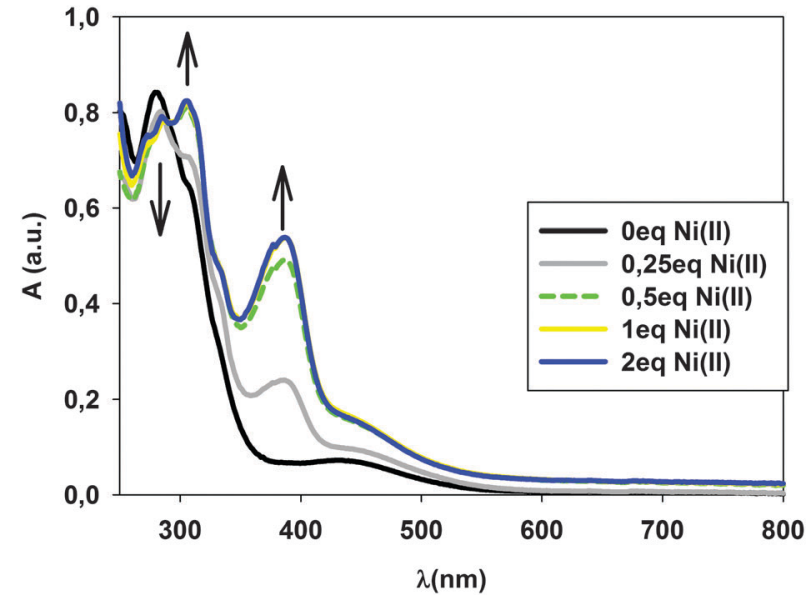

Fig. 7 UV-vis titration of ligand $\mathbf{1}\left(\mathrm{C}=1.25 \times 10^{-5} \mathrm{M}\right)$ by $\mathrm{Ni}\left(\mathrm{ClO}_{4}\right)_{2}$ in $\mathrm{DCM}-\mathrm{ACN}$ $(1 / 1, v / v)$.

they are known as chelating ligands for low oxidation states transition metals such as $\mathrm{Fe}^{2+}, \mathrm{Co}^{2+}, \mathrm{Cu}^{2+}, \mathrm{Zn}^{2+}, \mathrm{Cd}^{2+}, \mathrm{Ru}^{2+}$, $\mathrm{Os}^{2+}$, etc. It is therefore possible to generate and to isolate $\left.[\mathrm{M} \text { (terpyridine })_{2}\right]^{2+}$ complexes. Note that, in a previous recent study, ${ }^{17}$ the reaction of ligand 1 with 0.5 equiv. of iron(II)chloride followed by anion exchange afforded the complex $\left[\left\{\mathrm{Fe}(\mathbf{1})_{2}\right\}\left(\mathrm{PF}_{6}\right)_{2}\right]$, while the reaction of ligand $\mathbf{1}$ with one equivalent of a terpyridine-ruthenium-trichloride precursor followed by an anion exchange reaction afforded $\left[\{\mathrm{Ru}(\right.$ terpyridine $\left.)(\mathbf{1})\}\left(\mathrm{PF}_{6}\right)_{2}\right]$.

UV-visible electronic absorption titrations were performed by adding increasing amounts of a nickel perchlorate solution into a $\mathrm{CH}_{2} \mathrm{Cl}_{2}-\mathrm{CH}_{3} \mathrm{CN}$ solution of EDT-TTF-CONH-Terpy (1) (Fig. 7), resulting in a decrease of the band located at $281 \mathrm{~nm}$ and the appearance of new band around $386 \mathrm{~nm}$. This new absorption band corresponds to a ligand centered (LC, $\pi \rightarrow \pi^{*}$ and $n \rightarrow \pi^{*}$ ) absorption that appears upon formation of a complex and is likelyto be due to the conformational change (all trans to all cis) of the chelating terpyridine upon complexation. ${ }^{11 b, c, 24}$ The same behavior was observed upon progressive addition of $\mathrm{Zn}^{2+}$ or $\mathrm{Cd}^{2+}$ (Fig. S2, ESI $)$ ). In the case of $\mathrm{Fe}^{2+}$, in addition to the changes observed above, a metal to ligand charge transfer (MLCT) ${ }^{24}$ band, at around $576 \mathrm{~nm}$, is observed indicating the formation of $\left[\mathrm{Fe}(\mathbf{1})_{2}\right]^{2+}$ (Fig. S3, ESI $\dagger$ ). Note that, no additional absorption changes were observed upon introduction of more than 0.5 equiv. of $\mathrm{M}\left(\mathrm{ClO}_{4}\right)_{2}$, as expected for the formation of $2: 1$ complexes.

A UV-visible electronic absorption titration study was carried out for ligand 2 in the presence of nickel perchlorate, under the same conditions as for ligand $\mathbf{1}$. The resulting electronic spectra (Fig. 8) show an absorbance increase of the band located at $277 \mathrm{~nm}$ and the appearance of new absorption shoulder centered at around $330 \mathrm{~nm}$. As for ligand 1, no change in the absorbance occurs upon addition of more than 0.5 equiv. of the metal cation, which again suggests the formation of a $\left[\mathrm{Ni}(\text { terpyridine })_{2}\right]^{2+}$ complex. The same behavior was observed upon progressive addition of $\mathrm{Zn}^{2+}$ or $\mathrm{Cd}^{2+}$ (Fig. S4 and S5, ESI $\dagger$ ). In the case of $\mathrm{Fe}^{2+}$, an additional MLCT band is observed, at around $566 \mathrm{~nm}$, indicating the formation of the $\left[\mathrm{Fe}(\mathbf{1})_{2}\right]^{2+}$ complex (Fig. S6, ESI $)$ ).

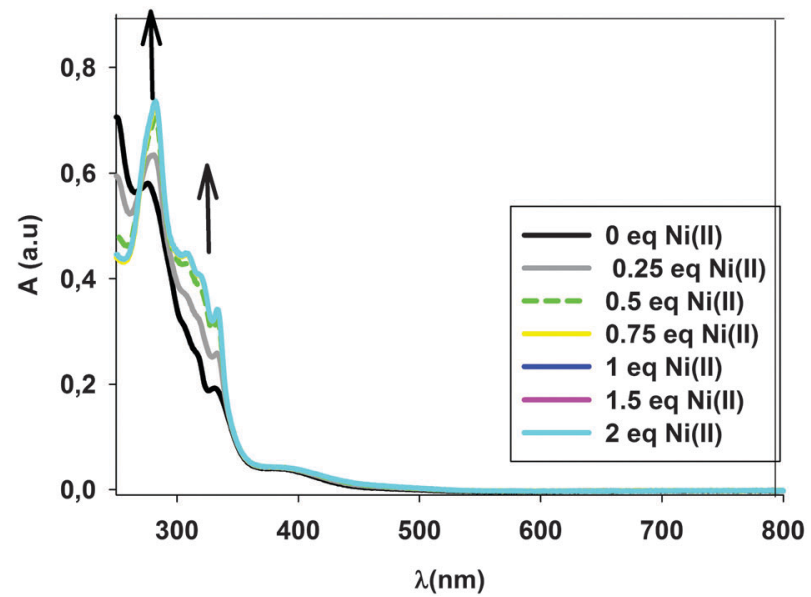

Fig. 8 UV-vis titration of ligand $2\left(C=1.25 \times 10^{-5} \mathrm{M}\right)$ by $\mathrm{Ni}\left(\mathrm{ClO}_{4}\right)_{2}$ in $\mathrm{DCM}-\mathrm{ACN}$ $(1 / 1, v / v)$.

The same experiment was led with ligand 2 and zinc chloride. The resulting electronic spectra (Fig. S7, ESI $\dagger$ ) show the same behavior as for the $\mathrm{Ni}$ (II) titration. Note that, in this case, no additional change in the spectra is observed upon addition of more than 1 equiv. of zinc chloride, suggesting the formation of a $[\mathrm{Zn}$ (terpyridine $\left.)(\mathrm{Cl})_{2}\right]$ complex.

\section{Complexation studies: electrochemical titrations}

Treatment of an electrolytic solution of ligand 1 or ligand $\mathbf{2}$ with metal perchlorate $\left(\mathrm{Ni}^{2+}, \mathrm{Zn}^{2+}, \mathrm{Cd}^{2+}\right.$ and $\left.\mathrm{Fe}^{2+}\right)$ in a $\mathrm{CH}_{2} \mathrm{Cl}_{2}-$ $\mathrm{CH}_{3} \mathrm{CN}$ mixture causes a slight positive shift (typically $+35 \mathrm{mV}$ for 1 and $+30 \mathrm{mV}$ for 2) of the first oxidation potential (Fig. 9 and Fig. S8-S10, ESI $\dagger$ for ligand 1; Fig. S11-S13, ESI $\dagger$ for ligand 2), a behavior which is assigned to the increased accepting character of the terpyridine fragment once the metal cation is bound. ${ }^{25}$ As for the UV-vis titration, the voltammograms remain unchanged upon addition of more than 0.5 equiv. of the metal cation. The electrochemical behavior of the resulting complexes is quite similar, suggesting a negligible influence of metal coordination on the oxidation potential of the TTF units, a situation often encountered when the ligand part and the TTF unit is well separated. ${ }^{26}$

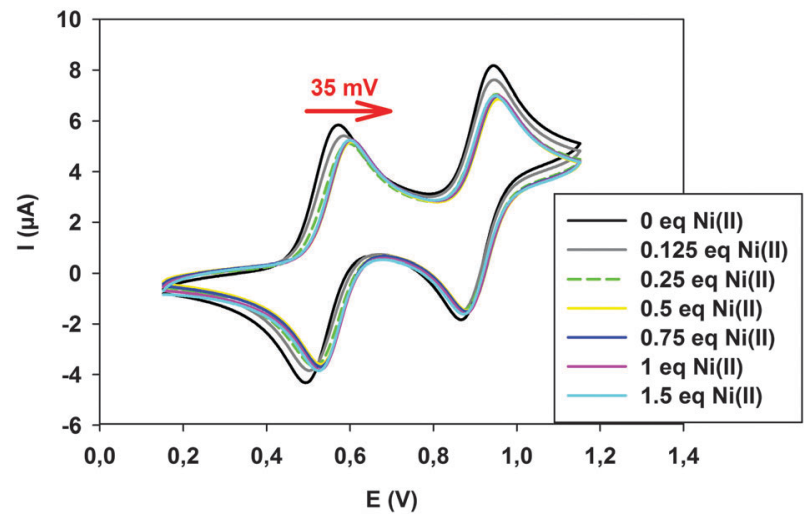

Fig. $9 \mathrm{CV}$ titration of (1) $10^{-3} \mathrm{~mol} \mathrm{~L}^{-1}$ in presence of $\mathrm{Ni}\left(\mathrm{ClO}_{4}\right)_{2}, \mathrm{CH}_{2} \mathrm{Cl}_{2}-\mathrm{CH}_{3} \mathrm{CN}$ $(1 / 1), v=100 \mathrm{mV} \mathrm{S}^{-1} \mathrm{Bu}_{4} \mathrm{NPF}_{6}\left(10^{-1} \mathrm{~mol} \mathrm{~L}^{-1}\right) / \mathrm{ECS}$. 
Note that, in the case of the $\mathrm{Fe}(\mathrm{II})$ complexes an additional oxidation band is observed around $0.576 \mathrm{~V}$, which is assigned to the oxidation of the $\left[\mathrm{Fe}(\text { terpyridine) }]^{2+}\right.$ fragment (Fig. S10 and S13, ESI $\dagger$ ).

\section{Synthesis and crystal structure of electroactive metal complexes}

It is clearly seen from the titration experiments that both ligands 1 and $\mathbf{2}$ are suitable for the preparation of electroactive neutral or charged metal complexes. We therefore investigated the coordination chemistry of these ligands with metal cations, as perchlorate or chloride salts. Accordingly, ligand 2 was reacted with 1 equiv. of zinc chloride $\left(\mathrm{ZnCl}_{2}\right)$ in a dicloromethane-acetonitrile mixture to afford, as expected, a neutral complex formulated as (MeS) $)_{3}$-TTF- $\mathrm{SCH}_{2} \mathrm{CONH}-\mathrm{TpyZnCl}_{2}$ (3), while by reaction with 0.5 equiv. of nickel perchlorate $\mathrm{Ni}\left(\mathrm{ClO}_{4}\right)_{2}$, a cationic structure formulated as $\left[\left\{(\mathrm{MeS})_{3}-\mathrm{TTF}-\mathrm{SCH}_{2} \mathrm{CONH}\right.\right.$ Tpy ${ }_{2} \mathrm{Ni}^{2+}$ (4) was formed (Scheme 3), confirming the observations made during the UV-vis and electrochemical titrations. These structures were confirmed by electrospray ionisation mass spectrometry (ESI-MS) with, in the case of complex 3, a peak at $m / z=762.61 \mathrm{~g} \mathrm{~mol}^{-1}$ corresponding to $\left[(\mathrm{MeS})_{3}\right.$-TTF$\left.\mathrm{SCH}_{2} \mathrm{CONH}-\mathrm{TpyZnCl}\right]^{+}$. In the case of complex 4, a monocationic

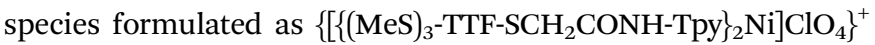
at $m / z=1482.46 \mathrm{~g} \mathrm{~mol}^{-1}$ and a dicationic species formulated as $\left[\left\{(\mathrm{MeS})_{3} \text {-TTF-SCH}_{2} \mathrm{CONH}^{-\mathrm{Tpy}}\right\}_{2} \mathrm{Ni}\right]^{2+}$ at $m / z=691.72 \mathrm{~g} \mathrm{~mol}^{-1}$ is observed.

Single crystals of both complexes $\mathbf{3}$ and $\mathbf{4}$ were obtained by diffusion of diethyl ether into a dichloromethane-methanol solution for 3 and into a dichloromethane-acetonitrile solution for 4. Analysis of the crystals confirms the observations made during the UV-vis and the electrochemical titrations.

(MeS) $)_{3}$-TTF-SCH ${ }_{2}$ CONH-Tpy-ZnCl $\mathbf{Z n O H}_{2} \cdot \mathbf{M e O H}$ (3) As expected, the resulting metal complex is composed of one ligand 2 coordinated to $\mathrm{ZnCl}_{2}$ through the three nitrogen atoms of terpyridine (Fig. 10), which acquires an all cis-conformation of the three pyridine cycles in contrast to the trans-conformation observed for free ligand 1 (see Fig. 1 and 4). The asymmetric unit of the triclinic $P \overline{1}$ crystal structure contains one $2-\mathrm{ZnCl}_{2}$ complex in a general position. The $\mathrm{S}_{4}$-TTF-fragment is essentially planar and makes significant angles with the amide and terpyridine moieties (Fig. 10 and Table 2). The intramolecular

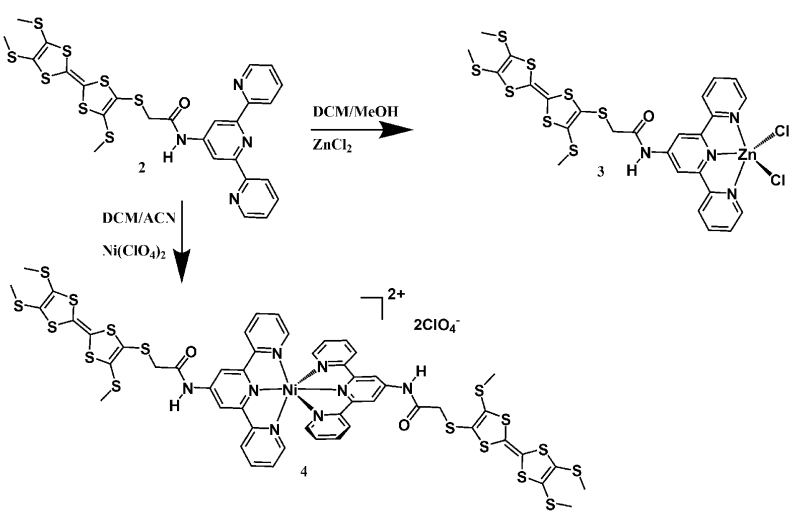

Scheme 3 Synthesis of metal complexes 3 and $\mathbf{4}$.

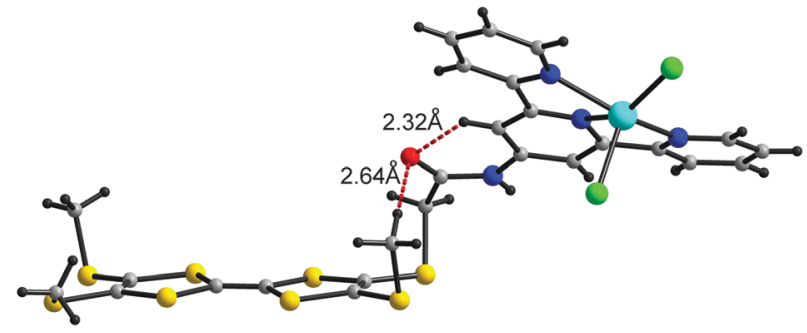

Fig. 10 One molecular unit of metal complex $2-\mathrm{ZnCl}_{2}$. Intramolecular $\mathrm{C}-\mathrm{H} \cdots \mathrm{O}$ contacts are shown by red dashed lines.

$\mathrm{C}_{\mathrm{sp} 2}-\mathrm{H} \cdots \mathrm{O}$ and $\mathrm{C}_{\mathrm{sp} 3}-\mathrm{H} \cdots \mathrm{O}$ hydrogen contacts, shown in Fig. 10, stabilize the molecular conformation. Methylsulfanyl (MeS) groups attached to the TTF-core give a higher flexibility to ligand 2, enabling it to adapt to its environment in comparison with the EDT group in ligand 1, but it makes it difficult to allow for infinite molecular stacks.

The zinc ion is pentacoordinated, its distorted square pyramidal coordination sphere being formed by three nitrogen atoms provided by the terpyridine unit and two chlorine atoms, with one $\mathrm{Cl}$ in the apical position. The $\mathrm{Zn}^{2+}$ ion is shifted away from the basal plane of square pyramid by about $0.57 \AA$. The $\mathrm{Zn}-\mathrm{Cl}$ bond lengths are 2.3139(9) and 2.2513(9) $\AA$ for the apical and basal $\mathrm{Cl}$ atoms, respectively. The $\mathrm{Zn}-\mathrm{N}$ bond between $\mathrm{Zn}$ and the central pyridine cycle of the terpyridine $[2.088(3) \AA]$ is slightly shorter than the bonds to lateral pyridine cycles [2.173(3) and 2.228(3) §]. The Tpy- $\mathrm{ZnCl}_{2}$ fragments of adjacent molecules are connected by $\mathrm{N}-\mathrm{H} \cdots \mathrm{Cl}$ and $\mathrm{C}_{\mathrm{sp} 2}-\mathrm{H} \cdots \mathrm{Cl}$ hydrogen bonds (Fig. 11), and also by short C. . C contacts $[\geq 3.319(5) \AA]$. Note that, the amide group forms a $\mathrm{N}-\mathrm{H} \cdots \mathrm{Cl}$ hydrogen bond with a short $\mathrm{H} \cdots \mathrm{Cl}$ distance $(2.33 \AA)$, whereas the carbonyl oxygen atom does not participate in the intermolecular hydrogen bonding.

Within the structure, Tpy- $\mathrm{ZnCl}_{2}$ moieties form segregated layers interleaved in the $c$-direction with TTF-based layers (Fig. 12). All the $\mathrm{S}_{4}$-TTF units within the layer are parallel and

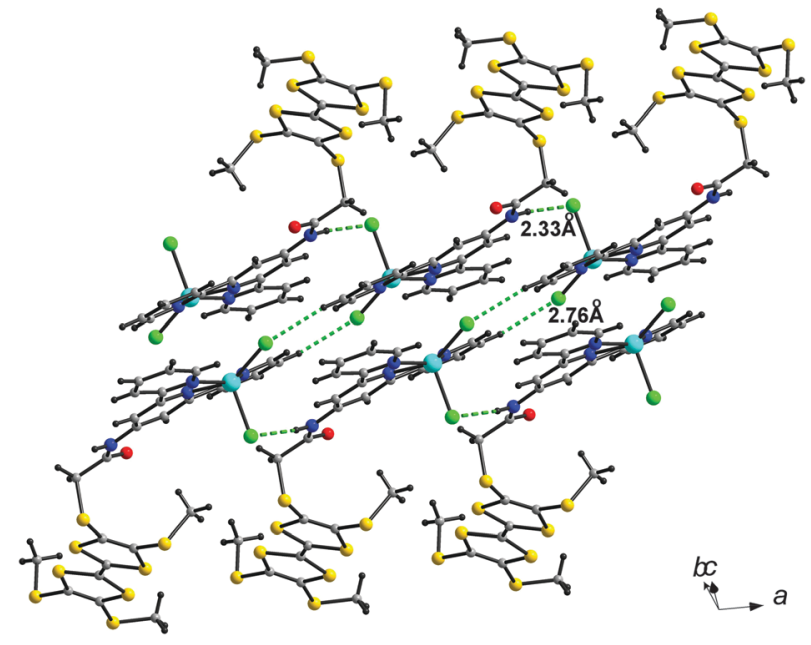

Fig. 11 Packing of the $\mathrm{Tpy}-\mathrm{ZnCl}_{2}$ layer and intermolecular hydrogen bonding in the structure of $2-\mathrm{ZnCl}_{2} \cdot \mathrm{MeOH}$ (3). 


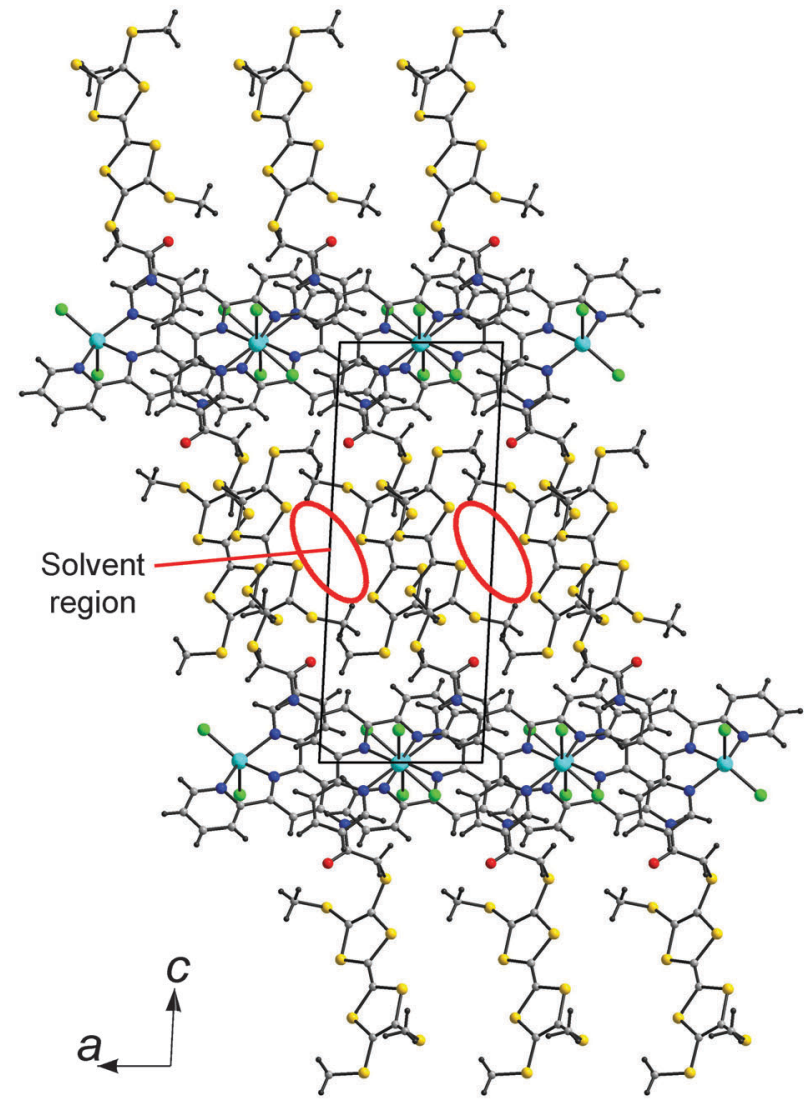

Fig. 12 Layered structure of $2-\mathrm{ZnCl}_{2} \cdot \mathrm{MeOH}$ (3) viewed along $b$. $\mathrm{MeOH}$ is located inside the regions delineated by red cycles.

form well-separated dimers with an interplane distance of 3.45(2) $\AA$ and ring-over-bond overlap. However, the $\mathrm{S}_{4}$-TTF fragments are less tightly packed than the Tpy- $\mathrm{ZnCl}_{2}$ fragments: shortened intradimer contacts in the $\mathrm{S}_{4}$-TTF layer are not observed and atoms of the (MeS) $)_{3}$-TTF moiety have larger thermal displacement parameters than other atoms of the molecule. Disordered methanol molecules are disposed between the dimers. They could not be reliably modeled during the refinement but their scattering contribution was taken into account using the SQUEEZE/PLATON procedure. Free voids of $156 \AA^{3}$, shown inside the red ovals in Fig. 12, contain about 35 electrons. This corresponds to two methanol molecules per unit cell or one $\mathrm{MeOH}$ molecule per formula unit.

$\left[\left\{(\mathrm{MeS})_{3} \text {-TTF-SCH} \mathrm{CHONH}_{2} \mathrm{CPyy}\right\}_{2} \mathrm{Ni}\right] \cdot\left(\mathrm{ClO}_{4}\right)_{2} \cdot \mathbf{0 . 5}\left(\mathrm{H}_{2} \mathrm{O}\right)(\mathbf{4})$. Crystals of $2_{2} \mathrm{Ni} \cdot\left(\mathrm{ClO}_{4}\right)_{2} \cdot 0.5\left(\mathrm{H}_{2} \mathrm{O}\right)$ have a triclinic unit cell and $P \overline{1}$ symmetry with one formula unit in the asymmetric part. All the molecules occupy general positions. Two crystallographically independent ligands (2) are coordinated to the same nickel(II) ion yielding a $2_{2} \mathrm{Ni}$ complex (Fig. 13). Central $\mathrm{C}=\mathrm{C}$ double bond lengths in both TTF fragments, 1.32(2) and 1.33(2) A, are characteristic of the neutral TTF state; all the positive charges of the complex are concentrated on the $\mathrm{Ni}^{2+}$ ion. The two TTF-moieties in the $\mathrm{Ni}$ complex are nearly perpendicular to each other [dihedral angle between their central $\mathrm{C}_{2} \mathrm{~S}_{4}$ fragments is $\left.83.5(1)^{\circ}\right]$. Nitrogen atoms form a distorted octahedron around the $\mathrm{Ni}^{2+}$ cation.

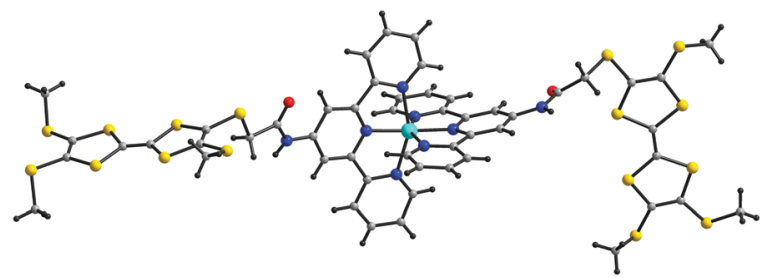

Fig. 13 Molecular unit of $\left[2_{2} \mathrm{Ni}\right]^{2+}$ metal complex (4).

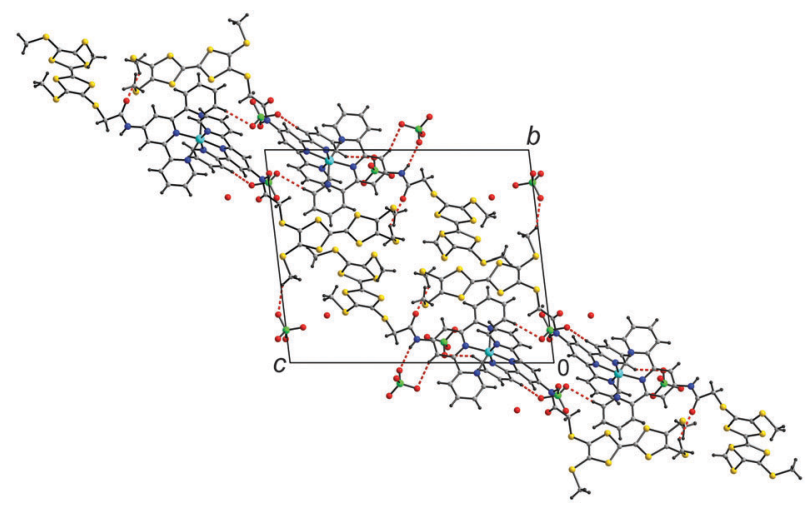

Fig. 14 Layered structure of $2_{2} \mathrm{Ni} \cdot\left(\mathrm{ClO}_{4}\right)_{2} \cdot 0.5\left(\mathrm{H}_{2} \mathrm{O}\right)$ viewed along a. The shortest hydrogen bonds, with $\mathrm{H}$...O distances of $2.07-2.55 \AA$ are shown by red dashed lines.

As for the $2-\mathrm{ZnCl}_{2}$ complex, $\mathrm{Ni}-\mathrm{N}$ bonds involving the central pyridine cycles $[2.002(9)$ and $2.008(8) \AA]$ are shorter than the bonds to the lateral ones [2.107-2.141(9) $\AA]$. Apparently, this difference is likely to result from geometrical reasons rather than the Jahn-Teller effect.

$\mathrm{Ni}-\mathrm{Tpy}_{2}$ and $(\mathrm{MeS})_{3}$-TTF fragments are separated into layers parallel to the $a c$ plane (Fig. 14). As shown in Fig. 14, a large number of hydrogen bonds between the cationic $2_{2} \mathrm{Ni}^{2+}$ complexes and anions are found; the shortest hydrogen bonds are formed with the $\mathrm{N}-\mathrm{H}$ hydrogen bond donors of the amide groups as they are activated in the presence of the positive charge on the nickel complex; the corresponding $\mathrm{H} \cdots \mathrm{O}$ distances are 2.07 and $2.18 \AA$.

\section{Conclusions}

Two multifunctional ligands, which associate an electrondonating TTF unit and an electron accepting/coordinating terpyridine moiety, have been prepared using straightforward synthetic strategies. Ligand 1 crystallizes as DMSO and $\mathrm{MeOH}$ solvates and an in-depth analysis of their crystal structures allows to decipher their pattern of assemblies in the solid state. Electronic spectra demonstrate intramolecular communication between the electron donor and acceptor fragments in ligands 1 and 2. Transition metal titration experiments showed that the two ligands are suitable for the preparation of neutral and charged electroactive metal complexes. Reaction of ligand 2 with 1 equiv. of $\mathrm{ZnCl}_{2}$ resulted in the formation of a neutral $\mathrm{Zn}$ (II) complex (3), while reaction with 0.5 equiv. of $\mathrm{Ni}\left(\mathrm{ClO}_{4}\right)_{2}$ 
provided a cationic Ni(II) complex (4). Both complexes were characterized in the solid state, the results confirmed the observations made during the metal titration experiments. The electrochemical studies of the ligands and of the resulting metal complexes, suggest that these compounds are useful candidates for the preparation of radical cation salts.

\section{Acknowledgements}

Work at Angers was supported by a CMEP program (PHC Tassili 08MDU730) and a joint CNRS-Russian Federation grants PICS 6028 and RFBR-CNRS 12-03-91059.

\section{Notes and references}

1 M. Bendikov, F. Wudl and D. F. Perepichka, Chem. Rev., 2004, 104, 4891-4945.

2 (a) P. Batail, Chem. Rev., 2004, 104, 4887-4890; (b) J. M. Williams, J. R. Ferraro, R. J. Thorn and L. C. Murphy, Nature, 1984, 309, 119-126.

3 (a) M. B. Nielsen, C. Lomholt and J. Becher, Chem. Soc. Rev., 2000, 29, 153-164; (b) J. L. Segura and N. Martin, Angew. Chem., Int. Ed., 2001, 40, 1372-1409; (c) D. Canevet, M. Salle, G. X. Zhang, D. Q. Zhang and D. B. Zhu, Chem. Commun., 2009, 2245-2269; (d) M. R. Bryce, J. Mater. Chem., 2000, 10, 589-598; (e) J. Yamada and T. Sugimoto, TTF Chemistry: Fundamentals \& Applications of Tetrathiafulvalene, Kodansha (Tokyo) and Springer (Berlin, Heidelberg, New York), 2004.

4 (a) E. Coronado, J. R. Galan-Marcos, C. J. Gomez-Garcia and V. Laukhin, Nature, 2000, 408, 447-449; (b) E. Coronado and P. Day, Chem. Rev., 2004, 104, 5419-5448; (c) M. Nihei, N. Takahashi, H. Nishikawa and H. Oshio, Dalton Trans., 2011, 40, 2154-2156.

5 For recent reviews, see: (a) D. Lorcy, N. Bellec, M. Fourmigué and N. Avarvari, Coord. Chem. Rev., 2009, 253, 1398-1438; (b) M. Shatruk and L. Ray, Dalton Trans., 2010, 39, 11105-11121.

6 (a) N. Avarvari, D. Martin and M. Fourmigué, J. Organomet. Chem., 2002, 643-644, 292-300; (b) P. Pellon, G. Gachot, J. Le Bris, S. Marchin, R. Carlier and D. Lorcy, Inorg. Chem., 2003, 42, 2056-2060; (c) N. Avarvari and M. Fourmigué, Chem. Commun., 2004, 1300-1301; (d) C. Réthoré, M. Fourmigué and N. Avarvari, Chem. Commun., 2004, 1384-1385; (e) T. Devic, P. Batail, M. Fourmigué and N. Avarvari, Inorg. Chem., 2004, 43, 3136-3141; $(f)$ C. Gouverd, F. Biaso, L. Cataldo, T. Berclaz, M. Geoffroy, E. Levillain, N. Avarvari, M. Fourmigué, F. X. Sauvage and C. Wartelle, Phys. Chem. Chem. Phys., 2005, 7, 85-93.

7 A. Kobayashi, E. Fujiwara and H. Kobayashi, Chem. Rev., 2004, 104, 5243-5264 (and references therein).

8 J. Massue, N. Bellec, S. Chopin, E. Levillain, T. Roisnel, R. Clérac and D. Lorcy, Inorg. Chem., 2005, 44, 8740-8748.

9 (a) F. Setifi, L. Ouahab, S. Golhen, Y. Yoshida and G. Saito, Inorg. Chem., 2003, 42, 1791-1793; (b) S.-X. Liu, S. Dolder,
P. Franz, A. Neels, H. Stoeckli-Evans and S. Decurtins, Inorg. Chem., 2003, 42, 4801-4803; (c) T. Devic, N. Avarvari and P. Batail, Chem.-Eur. J., 2004, 10, 3697-3707; (d) J.-Y. Balandier, M. Chas, S. Goeb, P. I. Dron, D. Rondeau, A. Belyasmine, N. Gallego and M. Sallé, New J. Chem., 2011, 35, 165-168; (e) K. S. Gavrilenko, Y. Le Gal, O. Cador, S. Golhen and L. Ouahab, Chem. Commun., 2007, 280-282; $(f)$ Y. Geng, X.-J. Wang, B. Chen, H. Xue, Y.-P. Zhao, S. Lee, C.-H. Tung and L.-Z. Wu, Chem.-Eur. J., 2009, 15, 5124-5129; ( $g$ ) S. V. Kolotilov, O. Cador, F. Pointillart, S. Golhen, Y. Le Gal, K. S. Gavrilenko and L. Ouahab, J. Mater. Chem., 2010, 20, 9505-9514; (h) S.-X. Liu, C. Ambrus, S. Dolder, A. Neels and S. Decurtins, Inorg. Chem., 2006, 45, 9622-9624; (i) T. Devic, P. Batail and N. Avarvari, Chem. Commun., 2004, 1538-1539.

10 (a) M. Chahma, N. Hassan, A. Alberola, H. Stoeckli-Evans and M. Pilkington, Inorg. Chem., 2007, 46, 3807-3809; (b) J. Qin, C.-X. Qian, N. Zhou, R.-M. Zhu, Y.-Z. Li, J.-L. Zuo and X.-Z. You, Eur. J. Inorg. Chem., 2012, 234-245; (c) G. Nita, D. Branzea, F. Pop, A. El-Ghayoury and N. Avarvari, Crystals, 2012, 2, 338-348.

11 (a) A. Bencini and V. Lippolis, Coord. Chem. Rev., 2010, 254, 2096-2180; (b) A. M. W. Cargill Thompson, Coord. Chem. Rev., 1997, 160, 1-52; (c) U. S. Schubert, H. Hofmeier and G. R. Newkome, Modern Terpyridine Chemistry, Wiley-VCH, Weinheim, 2006.

12 (a) T. Devic, N. Avarvari and P. Batail, Chem.-Eur. J., 2004, 10, 3697-3707; (b) T. Devic, D. Rondeau, Y. Şahin, E. Levillain, R. Clérac, P. Batail and N. Avarvari, Dalton Trans., 2006, 1331-1337; (c) K. Hervé, S.-X. Liu, O. Cador, S. Golhen, Y. Le Gal, A. Bousseksou, H. Stoeckli-Evans, S. Decurtins and L. Ouahab, Eur. J. Inorg. Chem., 2006, 3498-3502; (d) S. Campagna, S. Serroni, F. Puntoriero, F. Loiseau, L. De Cola, C. J. Kleverlaan, J. Becher, A. P. Sørensen, P. Hascoat and N. Thorup, Chem.-Eur. J., 2002, 8, 4461-4469.

13 (a) K. S. Bang, M. B. Nielsen, R. Zubarev and J. Becher, Chem. Commun., 2000, 215-216; (b) L. K. Keniley Jr, L. Ray, K. Kovnir, L. A. Dellinger, J. M. Hoyt and M. Shatruk, Inorg. Chem., 2010, 49, 1307-1309; (c) N. Dupont, Y.-F. Ran, H.-P. Jia, J. Grilj, J. Ding, S.-X. Liu, S. Decurtins and A. Hauser, Inorg. Chem., 2011, 50, 3295-3303.

14 Q. Wang, P. Day, J.-P. Griffiths, H. Nie and J. D. Wallis, New J. Chem., 2006, 30, 1790-1800.

15 G. M. Sheldrick, $S A D A B S$, University of Göttingen, Germany, 1996.

16 G. M. Sheldrick, Acta Crystallogr., Sect. A: Found. Crystallogr., 2008, 64, 112-122.

17 K. Iliopoulos, A. El-Ghayoury, H. El Ouazzani, M. Pranaitis, E. Belhadj, E. Ripaud, M. Mazari, M. Sallé, D. Gindre and B. Sahraoui, Opt. Express, 2012, 20, 25311-25316.

18 K. Heuzé, M. Fourmigué and P. Batail, J. Mater. Chem., 1999, 9, 2373-2379.

19 T. Mutai, J.-D. Cheon, S. Arita and K. Araki, J. Chem. Soc., Perkin Trans. 2, 2001, 1045-1050. 
20 J. Becher, J. Lau, P. Leriche, P. Moerk and N. Svenstrup, Chem. Commun., 1994, 2715-2716.

21 (a) S. A. Baudron, P. Batail, C. Rovira, E. Canadell and R. Clérac, Chem. Commun., 2003, 1820-1821; (b) M. Fourmigué and P. Batail, Chem. Rev., 2004, 104, 5379-5418.

22 K. Heuzé, M. Fourmigué and P. Batail, J. Mater. Chem., 1999, 9, 2373-2379.
23 R. Andreu, I. Malfant, P. G. Lacroix and P. Cassoux, Eur. J. Org. Chem., 2000, 737-741.

24 P.-T. Chou and Y. Chi, Chem.-Eur. J., 2007, 13, 380-395.

25 J. Y. Balandier, A. Belyasmine and M. Sallé, Eur. J. Org. Chem., 2008, 269-276.

26 D. Branzea, A. Fihey, T. Cauchy, A. El-Ghayoury and N. Avarvari, Inorg. Chem., 2012, 51, 8545-8556. 